\title{
Estrogen Permits Vasopressin Signaling in Preoptic Kisspeptin Neurons in the Female Mouse
}

\author{
-Richard Piet, ${ }^{1}$ Antoine Fraissenon, ${ }^{1}$ Ulrich Boehm, ${ }^{2}$ and ${ }^{\circledR}$ Allan E. Herbison ${ }^{1}$ \\ ${ }^{1}$ Centre for Neuroendocrinology and Department of Physiology, Otago School of Medical Sciences, University of Otago, 9054 Dunedin, New Zealand, and \\ ${ }^{2}$ Department of Pharmacology and Toxicology, University of Saarland School of Medicine, D-66421 Homburg, Germany
}

The cellular mechanisms governing the impact of the central circadian clock on neuronal networks are incompletely understood. We examine here the influence of the suprachiasmatic nucleus output neuropeptide arginine-vasopressin (AVP) on the activity of preoptic area kisspeptin neurons. These cells integrate circadian and hormonal signals within the neuronal network that regulates fertility in females. Electrophysiological recordings in brain slices from kisspeptin-GFP mice showed that AVP dose-dependently increased the firing rate of most kisspeptin neurons. These actions were mediated directly at the kisspeptin neuron. Experiments in mice expressing the calcium indicator GCaMP3 in kisspeptin neurons enabled simultaneous monitoring of intracellular calcium concentrations $\left(\left[\mathrm{Ca}^{2+}\right]_{\mathrm{i}}\right)$ in multiple cells and revealed that AVP increased $\left[\mathrm{Ca}^{2+}\right]_{\mathrm{i}}$ in $>80 \%$ of diestrous kisspeptin neurons via a mechanism involving voltage-gated calcium channels. We next examined whether AVP signaling in kisspeptin neurons was time and ovarian cycle dependent. AVP exerted the same effects on diestrous and proestrous days of the ovarian cycle, whether hours before [zeitgeber time 4 (ZT4)-ZT6] or just before (ZT10) the expected time of the proestrous preovulatory luteinizing hormone surge. Remarkably, however, AVP signaling was critically dependent on circulating ovarian steroids as AVP no longer excited preoptic kisspeptin neurons in ovariectomized mice, an effect that was fully restored by estradiol treatment. Together, these studies show that AVP exerts a potent and direct stimulatory influence upon the electrical activity and $\left[\mathrm{Ca}^{2+}\right]_{\mathrm{i}}$ of most preoptic kisspeptin neurons. Unexpectedly, estrogen is found to permit circadian AVP signaling at preoptic kisspeptin neurons rather than dynamically modulate its activity throughout the estrous cycle.

Key words: circadian system; GnRH; ovarian steroids; ovulation

\section{Introduction}

Daily rhythms in physiology and behavior are orchestrated by a central biological clock located in the suprachiasmatic nucleus (SCN; Moore and Eichler, 1972; Stephan and Zucker, 1972). Although the molecular clockwork governing timekeeping within the SCN is becoming increasingly understood (Partch et al., 2014), knowledge of how SCN neurons coordinate the activity of downstream neural networks and encode rhythmicity within these networks remains incomplete (Li et al., 2012).

One such neuronal network that is dramatically influenced by the SCN is that controlling fertility in female rodents. In this network, neurons are required to sense fluctuating levels of circulating estradiol, occurring over a $4-5 \mathrm{~d}$ period, in concert with the light/dark cycle to generate the preovulatory gonadotropin-

Received Nov. 5, 2014; revised March 8, 2015; accepted March 25, 2015.

Author contributions: R.P. and A.E.H. designed research; R.P. and A.F. performed research; U.B. contributed unpublished reagents/analytic tools; R.P., A.F., and A.E.H. analyzed data; R.P. and A.E.H. wrote the paper.

This work was supported by a grant from the Health Research Council of New Zealand (to A.E.H.). A.F. (presently at IMaLis Program, Ecole Normale Supérieure, Paris, France) was supported by "Fondation de I'Université Jean Monnet" and "L'École de I'Inserm Liliane Bettencourt." We thank Rob Porteous and Katja Czieselsky for technical assistance; and Drs. Karl Iremonger and Xinhuai Liu for their comments on an earlier draft of the manuscript.

The authors declare no competing financial interests.

Correspondence should be addressed to Allan E. Herbison, Centre for Neuroendocrinology and Department of Physiology, Otago School of Medical Sciences, University of Otago, P.0. Box 56, Dunedin 9054, New Zealand. E-mail: allan.herbison@otago.ac.nz.

DOI:10.1523/JNEUROSCI.4587-14.2015

Copyright $\odot 2015$ the authors $\quad 0270-6474 / 15 / 356881-12 \$ 15.00 / 0$ releasing hormone $(\mathrm{GnRH})$ surge only in the afternoon of proestrus (Everett and Sawyer, 1950; Legan and Karsch, 1975; Legan et al., 1975). There is substantial evidence that the integration of hormonal and circadian signals occurs within the anteroventral periventricular nucleus or, more widely, the rostral periventricular area of the third ventricle (RP3V; Kriegsfeld and Silver, 2006; de la Iglesia and Schwartz, 2006; Herbison, 2008). RP3V neurons express estrogen receptor $\alpha(\mathrm{ER} \alpha)$, are innervated by SCN neurons, and project directly to the final output cells of the network, the GnRH neurons (Watson et al., 1995; de la Iglesia et al., 1995; Wintermantel et al., 2006; Herbison, 2008).

Kisspeptin neurons within the RP3V have recently emerged as an important cellular locus where estrogen and circadian cues converge to control the GnRH surge (Robertson et al., 2009; Xu et al., 2011; Smarr et al., 2012). RP3V kisspeptin neurons express $\mathrm{ER} \alpha$ (Smith et al., 2006; Clarkson et al., 2008) and are innervated by SCN neurons expressing arginine-vasopressin (AVP; Vida et al., 2010; Williams et al., 2011), an SCN output neuropeptide that is thought to play a crucial role in the generation of the $\mathrm{GnRH}$ surge (Funabashi et al., 1999; Palm et al., 1999; Miller et al., 2006; Li et al., 2012; Owen et al., 2013). As such, it is presently suspected that RP3V kisspeptin neurons act as coincidence detectors for the independent hormonal and circadian signals driving the output of this network at the time of the GnRH surge.

In the present study, we examined whether estradiol and SCN AVP inputs are indeed integrated at the RP3V kisspeptin neuron 
in female mice. Using transgenic mouse models that enable electrophysiological analyses and calcium imaging of RP3V kisspeptin neurons, we first established that AVP is a potent activator of kisspeptin neuron activity. We then questioned whether AVP signaling in kisspeptin neurons encodes zeitgeber time (ZT) and hormonal status by investigating the impact of AVP at different times of the day and at different stages of the ovarian cycle. Subsequently, we undertook studies in ovariectomized, estradiolreplaced mice to evaluate the full impact of gonadal steroids upon AVP signaling at the kisspeptin neuron. Our results suggest unexpected cellular mechanisms through which RP3V kisspeptin neurons integrate daily SCN signals and the slowly fluctuating estradiol concentrations occurring across the ovarian cycle.

\section{Materials and Methods}

Animals, surgery, and brain slice preparation. Adult, female, 2- to 7-month-old kisspeptin-IRES-Cre ${ }^{+/-} / \mathrm{ROSA}^{26-C A G-} \mathrm{GFP}^{+/-}$(KissGFP; Mayer et al., 2010) and kisspeptin-IRES-Cre ${ }^{+/-} /$ROSA26-CAG- $^{-}$ GCaMP3 $^{+/-}$[Kiss-GCaMP3 (http://jaxmice.jax.org/strain/014538.html); Zariwala et al., 2012] mice were group housed under conditions of controlled temperature $\left(22 \pm 2^{\circ} \mathrm{C}\right)$ and lighting $(12 \mathrm{~h}$ light/dark cycles $)$ with ad libitum access to food and water. All mice used in this study were bred from homozygous kisspeptin-IRES-Cre mice crossed with homozygous Credependent GFP (ROSA26-CAG- $\tau$ GFP) or GCaMP3 (ROSA26-CAGGCaMP3) mice. The University of Otago Animal Ethics Committee approved all animal experimental protocols.

Estrous cycle stage was determined by daily vaginal smears each morning, and mice exhibiting at least two regular 4 or $5 \mathrm{~d}$ estrous cycles were studied either on diestrus (appearance of leukocytes) or proestrus (appearance of nucleated epithelial cells). In some experiments, mice underwent bilateral ovariectomy (OVX) under anesthesia and were studied 2 weeks later. In estrogen replacement experiments, mice underwent bilateral OVX under anesthesia and were given subcutaneous SILASTIC implants containing $17 \beta$-estradiol ( $1 \mu \mathrm{g} / 20 \mathrm{~g}$ body weight), as described previously (Bronson, 1981; Piet et al., 2013). This method generates blood estradiol levels in estradiol- and OVX-treated mice ( 30 pg/ml) that are comparable to those found in intact female mice (Bronson, 1981). Implants were replaced after $7 \mathrm{~d}$, and implanted mice were studied $14 \mathrm{~d}$ post-OVX.

In our mouse colony, the proestrus preovulatory luteinizing hormone (LH) surge occurs between ZT11 and ZT14 (K. Czieselsky and A.E. Herbison, unpublished observations). Thus, in most experiments mice were killed 4-6 h after the onset of the light phase (ZT4-ZT6), with recordings performed between ZT6 and ZT11. In one series of experiments, mice were killed at ZT10, just before the expected time of the LH surge in proestrous mice, and recordings were carried out between ZT11 and ZT14.

Mice were killed by cervical dislocation and decapitated, and their brains were quickly removed. Coronal brain slices (200 $\mu \mathrm{m}$ thick) including the RP3V were cut with a vibratome (VT1000S, Leica) in an ice-cold solution containing the following (in $\mathrm{mM}$ ): $\mathrm{NaCl} 87, \mathrm{KCl} 2.5$, $\mathrm{NaHCO}_{3} 25, \mathrm{NaH}_{2} \mathrm{PO}_{4} 1.25, \mathrm{CaCl}_{2} 0.5, \mathrm{MgCl}_{2} 6$, glucose 25, and sucrose 75. Slices were then incubated at $30^{\circ} \mathrm{C}$ for at least $1 \mathrm{~h}$ in artificial CSF (aCSF) containing the following (in $\mathrm{mm}$ ): $\mathrm{NaCl} 120, \mathrm{KCl} 3, \mathrm{NaHCO}_{3} 26$, $\mathrm{NaH}_{2} \mathrm{PO}_{4} 1, \mathrm{CaCl}_{2} 2.5, \mathrm{MgCl}_{2} 1.2$, and glucose 10 . All solutions were equilibrated with $95 \% \mathrm{O}_{2} / 5 \% \mathrm{CO}_{2}$.

Cell-attached recordings. Electrophysiological recordings of Kiss-GFP neurons were carried out as described previously (de Croft et al., 2012; Piet et al., 2013). Briefly, slices were placed under an upright microscope fitted for epifluorescence (Olympus) and constantly perfused (1.0-1.5 $\mathrm{mL} / \mathrm{min})$ with warm $\left(\sim 30^{\circ} \mathrm{C}\right)$ aCSF. RP3V GFP-expressing neurons located $-80 \mu \mathrm{m}$ lateral to the wall of the third ventricle (de Croft et al., 2012) were targeted for electrophysiological recordings. GFP-expressing neurons were first visualized by brief fluorescence illumination and subsequently approached using infrared differential interference contrast optics. In some experiments, pairs of Kiss-GFP and non-GFP neurons were recorded simultaneously. Recorded Kiss-GFP and non-GFP neu- rons were located in the vicinity of one another within the ipsilateral RP3V.

Spontaneous firing was recorded using the minimally invasive cellattached loose patch configuration. Recording electrodes (3-5 M $\Omega$ ) pulled from borosilicate capillaries (Warner Instruments) with a horizontal puller (Sutter Instruments) were filled with aCSF, including 10 mM HEPES. Low-resistance seals (10-30 M $\Omega$ ) were achieved by applying either no suction or the lowest amount of suction required to detect spontaneous spikes. No additional negative pressure was subsequently applied during the course of a recording. Spontaneous spikes were recorded in the voltage-clamp mode.

Electrophysiological signals were recorded using a Multiclamp 700B amplifier (Molecular Devices) connected to a Digidata 1440A digitizer (Molecular Devices). Signals were low-pass filtered at $3 \mathrm{kHz}$ before being digitized at a rate of $10 \mathrm{kHz}$ and stored on a personal computer. Signal acquisition was carried out with pClamp version 10 software (Molecular Devices).

In most experiments, the spontaneous firing of neurons was monitored in control aCSF for $>5$ min before a drug was applied in the bath for $1 \mathrm{~min}$. When testing the effect of different concentrations of AVP, individual neurons were each exposed to a single AVP concentration. In some experiments, antagonists were applied for $5 \mathrm{~min}$ before the effect of AVP was tested. Recordings in which the baseline firing was not stable or in which a clear recovery from the effect of a drug was not observed were not included in the analysis. In a subset of experiments, AVP was locally applied by pressure ejection ( $4-8 \mathrm{psi}$ ) from a patch pipette filled with aCSF containing $10 \mathrm{~mm}$ HEPES and $1 \mu \mathrm{M}$ AVP using a pneumatic PicoPump (PV820, Warner Precision Instruments). The "puff" pipette was placed $\sim 20 \mu \mathrm{m}$ from the recorded somata, and AVP was applied for $10 \mathrm{~s}$.

Spontaneous spikes were detected using the threshold-crossing method in pClamp 10. Spike time stamps were organized in $30 \mathrm{~s}$ bins for bath applications, and in $10 \mathrm{~s}$ bins for pressure applications. Average firing rates were compared over $1 \mathrm{~min}$ periods immediately before the puff, at the peak of the effect (typically 1-4 min following the application), and after a $10 \mathrm{~min}$ washout period for bath applications. For pressure applications, average firing rates were compared over $30 \mathrm{~s}$ periods (just before the puff, at the peak of the effect, and 3 min after the puff). Drugs were considered to have an effect if the firing rate changed by more than twice the SD of the basal firing rate. In recordings showing no change, the "effect" of a drug was measured 2 min following the application.

Intracellular calcium imaging. Slices obtained from Kiss-GCaMP3 mice were placed under an upright microscope (Olympus), constantly perfused $(1.0-1.5 \mathrm{~mL} / \mathrm{min})$ with warm $\left(\sim 30^{\circ} \mathrm{C}\right)$ aCSF and allowed to stabilize for $>15 \mathrm{~min}$. Variations in intracellular calcium concentration $\left(\left[\mathrm{Ca}^{2+}\right]_{\mathrm{i}}\right)$ were estimated by measuring GCaMP3 fluorescence changes in kisspeptin neurons. Slices were illuminated through a $40 \times$ immersion objective, using a xenon arc light source $(300 \mathrm{~W}$; filtered by a GFP filter cube, excitation 470-490 nm, Chroma) and the shutter of a $\lambda$ DG-4 (Sutter Instruments). Epifluorescence (long-pass filtered, $495 \mathrm{~nm}$; emission, 500-520 nm) was collected using a Hamamatsu ORCA-ER digital CCD camera. Light source, shutter, and camera were controlled and synchronized with the $\mu$ Manager version 1.4 software (Edelstein et al., 2010). A focal plane including several fluorescent somata was chosen, and acquisitions (100 ms light exposure at $2 \mathrm{~Hz}$ for $10-20 \mathrm{~min}$ ) were started. At the end of the experiments, the responsiveness of fluorescent cells in the slice was tested by applying AMPA $(30 \mu \mathrm{M})$. Drugs were applied in the bath for $1 \mathrm{~min}$.

For analysis, time series of images were processed in Image (Schneider et al., 2012). Regions of interest (ROIs), including individual in-focus fluorescent somata, were selected ( $7.7 \pm 0.5$ per slice; range, $4-11$ ROIs). Cells were excluded when fluorescence within ROIs appeared contaminated by fluorescence arising from neighboring cells in close apposition or from other fluorescent cells projecting neurites in the ROI. The average fluorescence intensity within each ROI was measured in each frame. Fluorescence intensity data were analyzed using scripts written in $\mathrm{R}$ (http://www.r-project.org/) or using pClamp. Relative fluorescence changes were calculated using the following formula: 
A Proestrus

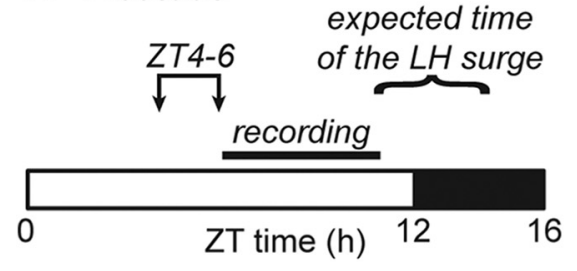

C

AVP $100 \mathrm{nM}$
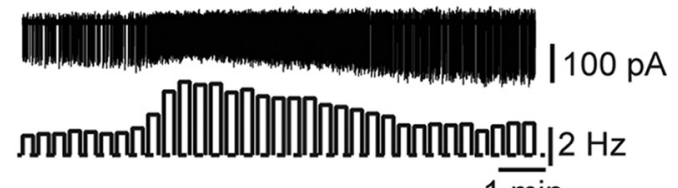

AVP $100 \mathrm{nM}$
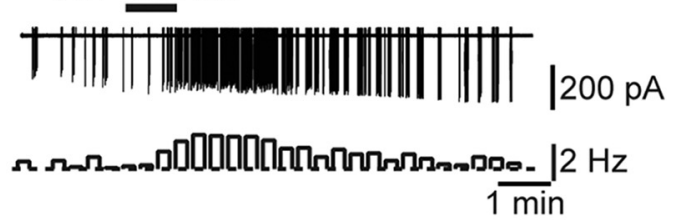

E

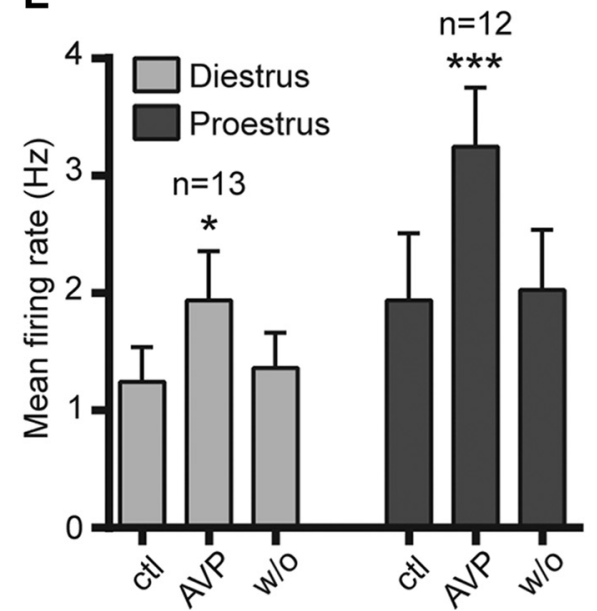

B Diestrus

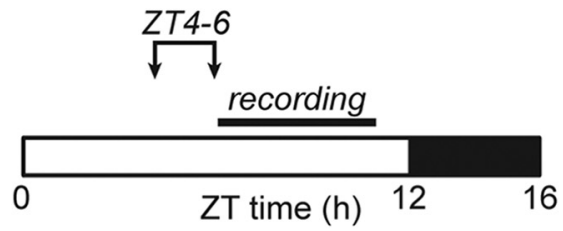

D

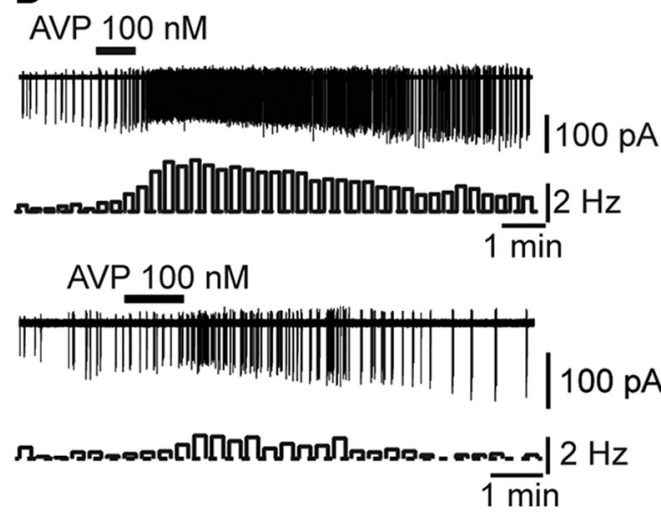

$\mathbf{F}$

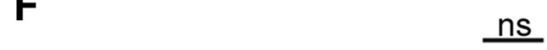

Figure 1. AVP increases RP3V kisspeptin neuron spontaneous firing in female mice. A, B, Timing of experiments in proestrus and diestrus. Mice were killed between ZT4 and ZT6 (arrows), and recordings were performed between ZT6 and ZT11. The expected time of the preovulatory LH surge occurring in proestrous mice is indicated in $A$. C, D, Example traces and corresponding rate meters (20 s bins) illustrating the excitatory effect of $100 \mathrm{~nm} \mathrm{AVP} \mathrm{on} \mathrm{the} \mathrm{spontaneous} \mathrm{firing} \mathrm{in} \mathrm{RP3V} \mathrm{kisspeptin} \mathrm{neurons} \mathrm{from} \mathrm{proestrous}(\boldsymbol{C})$ and diestrous (D) mice. $\boldsymbol{E}$, Summary bar graphs illustrating the significant effect of $100 \mathrm{~nm}$ AVP in diestrus (light gray) and proestrus (dark gray). ${ }^{*} p<0.05$ and ${ }^{* * *} p<0.001$, repeated-measures ANOVA. $\boldsymbol{F}$, Bar graphs summarizing the net effect of $10 \mathrm{~nm}, 100$ $\mathrm{nm}$, and $1 \mu \mathrm{M}$ AVP on the firing of diestrous and proestrous RP3V kisspeptin neurons. The number of recordings are indicated within the bars. ${ }^{a} p<0.05$ vs 10 and $100 \mathrm{~nm}$ diestrus; ${ }^{\mathrm{b}} p<0.05$ vs 10 nм proestrus; and ns not significant, two-way ANOVA with Bonferroni's post-tests. ctl, Control, w/0, washout.

$$
\frac{\Delta F}{F}=\frac{F_{t}-F}{F} * 100
$$

where $F$ is the baseline fluorescence intensity calculated as the mean fluorescence intensity over a $2 \mathrm{~min}$ period preceding drug applications, and $F_{t}$ is the fluorescence measured at any time point. For statistical comparisons, $\Delta F / F$ was averaged over 1 min periods in controls, in the presence of drugs and after washout.

Statistics. Statistical analyses were performed with Prism 6 (GraphPad Software). Values given in the text and illustrated in figures are the mean \pm SEM. The normality of data distribution in datasets was assessed using the D'Agostino and Pearson omnibus normality test. Nonparametric statistics were applied when datasets did not pass the normality test. The sample size used in statistical tests was given as the number of neurons. All experiments were replicated in at least three different mice in each group, and up to three slices were used in each mouse. Differences were considered significant for $p$ values $<0.05$.
Drugs. AMPA, DL-2-amino-5-phosphonopentanoic acid (AP5), AVP, 6-cyano-7-nitroquinoxaline-2,3-dione (CNQX), 6-imino-3-(4-ethoxyphenyl)-1(6H)-pyridazinebutanoic acid hydrobromide (gabazine), and $\left(\mathrm{d}(\mathrm{CH} 2) 5^{1}, \operatorname{Tyr}(\mathrm{Me})^{2}, \mathrm{Arg}^{8}\right)$-vasopressin (Manning Compound) were purchased from Tocris Bioscience. $\left(\mathrm{Thr}^{4}, \mathrm{Gly}^{7}\right)$-oxytocin (TGOT) was purchased from Bachem. Tetrodotoxin citrate (TTX) was purchased from Alomone Labs. AMPA, AP5, CNQX, gabazine, TGOT, and TTX were dissolved in water, AVP was dissolved in aCSF, and Manning Compound was dissolved in DMSO to a stock concentration, kept at $-20^{\circ} \mathrm{C}$ until use, and diluted to the appropriate concentration in aCSF.

\section{Results}

AVP excites RP3V kisspeptin neurons throughout the estrous cycle

As the circadian timing signal occurs in the few hours preceding the generation of the preovulatory LH surge (Everett and Sawyer, 
1950; Legan and Karsch, 1975; Christian and Moenter, 2008), we initially chose to kill mice at ZT4-ZT6 and to perform our recordings at ZT6-ZT11 (Fig. 1 A,B). We used cell-attached recordings to monitor the spontaneous firing of RP3V kisspeptin neurons in slices obtained from Kiss-GFP mice. We first investigated the effect of AVP on kisspeptin neuron firing during proestrus, the day the preovulatory $\mathrm{LH}$ surge is generated in intact mice. As reported previously, most RP3V kisspeptin neurons were spontaneously active and exhibited varied firing patterns (de Croft et al., 2012). A 1 min bath application of AVP (100 nM) increased spontaneous action potential firing in 10 of $12(83 \%)$ proestrous RP3V kisspeptin neurons (Fig. $1 C)$. Overall, AVP significantly and reversibly enhanced kisspeptin neuron firing (from $1.94 \pm 0.57$ to $3.25 \pm 0.50 \mathrm{~Hz}$; $F_{(2,22)}=27.25, p<0.001$, repeatedmeasures ANOVA; $n=12$ in three mice; Fig. 1E).

Because the LH surge is generated only on proestrus, we reasoned that the processing of daily SCN signals in RP3V kisspeptin neurons may vary during the estrous cycle. We therefore examined the effect of AVP in RP3V kisspeptin neurons from diestrous mice. Kisspeptin neuron spontaneous firing rates were not significantly different between diestrus and proestrus ( $p=0.28$, unpaired $t$ test) as previously reported (de Croft et al., 2012). AVP (100 nM) increased firing in 8 of 13 diestrous RP3V kisspeptin neurons (62\%; Fig. 1D), while it decreased firing in 1 cell $(8 \%)$, and overall caused a significant increase in kisspeptin neuron firing rates (from $1.24 \pm 0.30$ to $1.96 \pm 0.42 \mathrm{~Hz} ; F_{(2,24)}=5.249, p=0.013$, repeated-measures ANOVA; $n=13$ in seven mice; Fig. $1 E$ ).

Although it appeared larger on proestrus, the net effect of 100 nм AVP was not significantly different on diestrus and on proestrus $(0.71 \pm 0.30$ vs $1.31 \pm 0.25 \mathrm{~Hz}$, respectively; $p>0.05$, twoway ANOVA with Bonferroni's post-test; Fig. $1 F)$. We investigated this further by comparing the effect of AVP at two other concentrations (10 $\mathrm{nM}$ and $1 \mu \mathrm{M})$. The AVP-induced increase in firing was dose dependent as the effect of $1 \mu \mathrm{M}$ was significantly larger than that of $10 \mathrm{nM}$ in diestrus and proestrus $(p<0.05)$ and that of $100 \mathrm{~nm}$ in diestrus $(p<0.05$, two-way ANOVA with Bonferroni's post-tests; Fig. $1 F)$. However, the net effect of AVP was not significantly different ( $p>0.05$, two-way ANOVA with Bonferroni's post-tests) between the two cycle stages at any concentration (10 nM: diestrus, $0.31 \pm 0.14 \mathrm{~Hz}$; proestrus, $0.41 \pm 0.16 \mathrm{~Hz}$; $p>0.05$, both groups: $n=10$ in three mice; $1 \mu \mathrm{M}$ : diestrus, $2.30 \pm 0.78 \mathrm{~Hz}$; proestrus, $1.96 \pm 0.48 \mathrm{~Hz}$; $n=8$ in three mice and $n=9$ in three mice, respectively; Fig. $1 F$ ). Overall, whereas AVP concentration had a significant effect on cell firing $\left(F_{(2,56)}=10.47, p<0.001\right)$, there was no significant effect of cycle stage $(p=0.69)$, and no interaction between AVP concentration and cycle stage ( $p=0.43$, two-way ANOVA). Last, the proportion of RP3V kisspeptin neurons excited by AVP did not vary significantly in diestrous and proestrous mice at all concentrations
B Diestrus

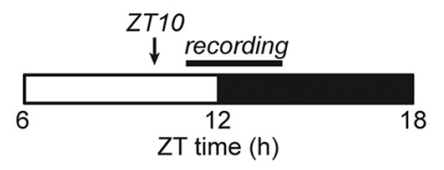

D

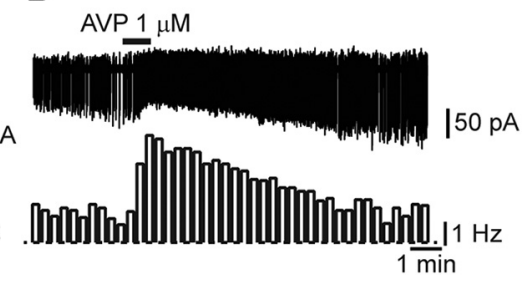
min

iestrus

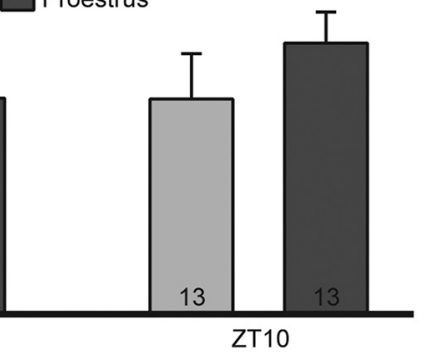

ZT4-6

ZT10

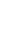

Figure 2. The excitatory effect of AVP is unchanged around the expected time of the LH surge. $A, B$, Timing of experiments in proestrus and diestrus. Mice were killed at the end of the light cycle (ZT10, arrow). Recordings were undertaken between ZT11 and . The expected time of the preovulatory LH surge occurring in proestrous mice is indicated in $A$. C, D, Example traces and expected time of the surge in proestrus and in a time-of-day control diestrous mice. E, Summary bar graph of the net effect of $1 \mu \mathrm{m}$ AVP on RP3V kisspeptin neuron firing in diestrous and proestrous females killed hours before (ZT4-ZT6) or just before (ZT10) the end of the light cycle. Bars for ZT4-ZT6 are from Figure $1 F$.

tested (10 nM: $40 \%$ vs $50 \%, p=1.00 ; 100$ nM: $62 \%$ vs $83 \%, p=0.38$; $1 \mu \mathrm{M}: 100 \%$ vs $88.9 \%, p=1.00$, respectively; Fisher's exact test).

RP3V kisspeptin neuron response to AVP is similar in diestrous and proestrous mice at the expected time of the $\mathrm{LH}$ surge

The results above indicate that the ability of RP3V kisspeptin neurons to respond to AVP remains unchanged across the estrous cycle. It remains possible, however, that differences in RP3V kisspeptin neuron responsiveness occur at times closer to the peak of the LH surge. To test this, proestrous mice were killed at ZT10, and recordings were undertaken between ZT11 and ZT14 (Fig. 2A), around the time when the LH surge is occurring. Diestrous mice that were killed and recorded at the same times of day were used as controls (Fig. 2B). AVP $(1 \mu \mathrm{M})$ increased firing on both diestrus and proestrus (in $92.3 \%$ of kisspeptin neurons each; Fig. 2C,D). The magnitude of the AVP effect was similar regardless of cycle stage (proestrus: $2.45 \pm 0.41 \mathrm{~Hz}, n=13$ in four mice; diestrus: $1.95 \pm 0.28 \mathrm{~Hz}, n=13$ in five mice; $p=0.32$, unpaired $t$ test; Fig. $2 E$ ). Of note, the effect of AVP on RP3V kisspeptin neuron firing at ZT10 was indistinguishable from that at ZT4-ZT6 (ZT effect, $p=0.88$, two-way ANOVA; Fig. 2E). Furthermore, the effect of AVP was similar during the day and during the night in diestrous mice (mice killed at ZT4-ZT5 and at ZT16-ZT17, respectively; data not shown).

Together, these observations show that the responses of RP3V kisspeptin neurons to AVP are not regulated in a diurnal or in an estrous cycle-dependent fashion. 
A
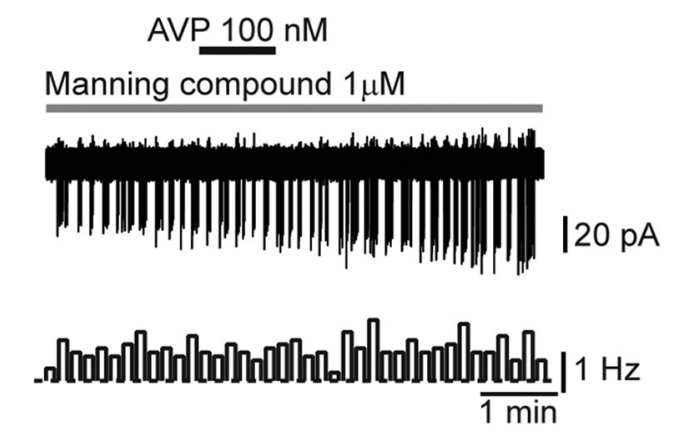

C

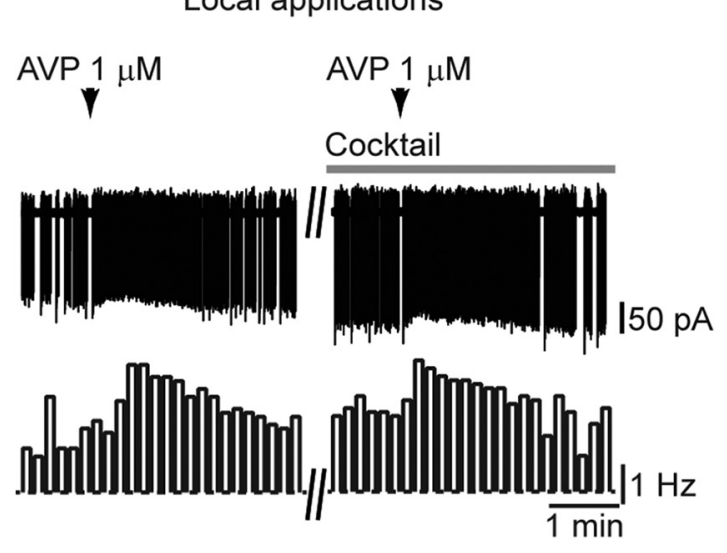

B

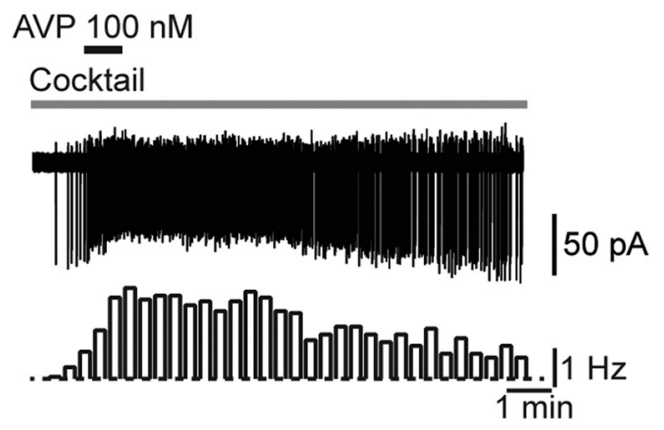

D

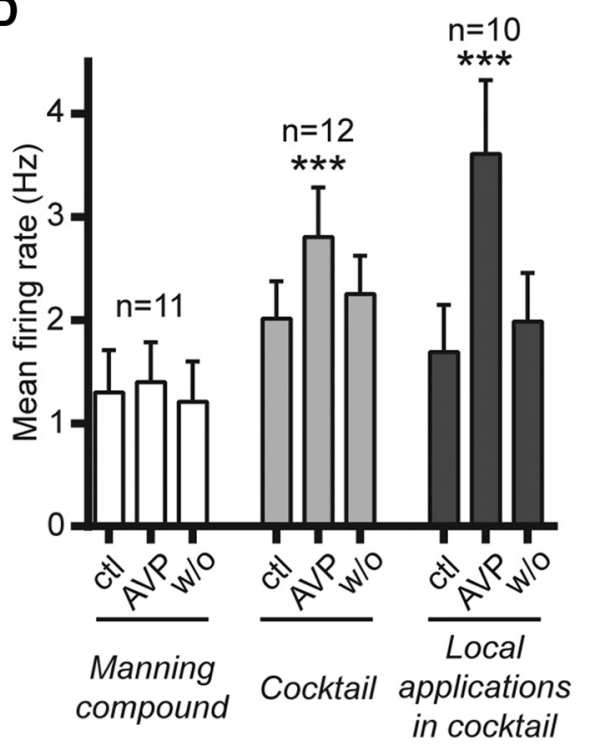

Figure 3. The effect of AVP is prevented by the Manning Compound and does not require fast synaptic transmission. $A$, Example trace and corresponding rate meter (10 s bins) showing that the Manning Compound (1 $\mu \mathrm{M}$; gray bar above trace) prevented the excitatory effect of AVP (100 nM) in an RP3V kisspeptin neuron. B, Sample trace and rate meter ( $20 \mathrm{~s}$ bins) illustrating the effect of AVP $(100 \mathrm{~nm})$ in the presence of an antagonist cocktail including CNQX, AP5, and gabazine to block AMPA, NMDA, and GABA $A_{A}$ receptors, respectively (gray bar above trace). C, Sample traces illustrating the effect of a local pressure application (10 s, arrows) of AVP $(1 \mu \mathrm{m})$ on an RP3V kisspeptin neuron (left). The effect is still seen in the presence of the antagonist cocktail (right). $\boldsymbol{D}$, Summary graph of the lack of effect of AVP in the presence of Manning Compound, and of the effect of AVP applied in the bath or locally on the firing of RP3V kisspeptin neurons in the presence of the cocktail. ${ }^{* *} p<0.001$, repeated-measures ANOVA and Friedman test. ctl, Control; w/o, washout.

\section{AVP acts at vasopressin 1a receptors in RP3V kisspeptin neurons}

Previous work indicated that rodent RP3V kisspeptin neurons express vasopressin 1a receptors (V1aRs; Williams et al., 2011). We therefore tested whether the Manning Compound, a potent V1aR antagonist with high selectivity over V2Rs (Manning et al., 2012), prevented the effect of AVP. These experiments were undertaken in diestrous mice during the day (mice killed at ZT4ZT6). AVP (100 nM) no longer increased spontaneous firing in the presence of $1 \mu \mathrm{M}$ Manning Compound in all but one RP3V kisspeptin neuron $(9 \% ; 1.30 \pm 0.41$ to $1.40 \pm 0.39 \mathrm{~Hz} ; p=0.27$, Friedman test; $n=11$ in four mice; Fig. $3 A, D$ ), suggesting that AVP acts at V1aRs to increase firing in RP3V kisspeptin neurons. Of note, Manning Compound itself had no effect on the spontaneous firing of these neurons $(1.39 \pm 0.50 \mathrm{vs} 1.39 \pm 0.53 \mathrm{~Hz} ; p=$ 0.84 , Friedman test; $n=8$ in three mice; data not shown) showing that, under our experimental conditions, there was no tone of endogenous AVP release in the vicinity of RP3V kisspeptin neurons.

The Manning Compound also acts as an antagonist at oxytocin receptors, whereas AVP is an oxytocin receptor agonist (Busnelli et al., 2013). It is therefore possible that some of the effects of AVP are mediated by oxytocin receptors in RP3V kisspeptin neu- rons. We thus sought to determine whether these neurons express functional oxytocin receptors using the selective oxytocin receptor agonist TGOT (Lowbridge et al., 1977). Bath applications of $2 \mathrm{~nm}$ TGOT, a concentration that is 10 -fold higher than the $\mathrm{EC}_{50}$ of this compound at oxytocin receptors but showing little binding at V1aRs (Busnelli et al., 2013), did not alter spontaneous firing in eight of nine (89\%) RP3V kisspeptin neurons and increased firing in one neuron. Overall, 2 nM TGOT did not significantly change firing in RP3V kisspeptin neurons (from $1.93 \pm 0.56$ to $2.08 \pm 0.52 \mathrm{~Hz} ; n=9$ in four mice; $p=0.36$, Friedman test). These data suggest that RP3V kisspeptin neurons do not express functional oxytocin receptors. Thus, the effect of AVP on RP3V kisspeptin neuron firing is likely mediated by V1aRs.

The next experiments were aimed at determining whether the effects of AVP were direct on RP3V kisspeptin neurons. To address this issue, we first performed recordings in the presence of a cocktail of CNQX (10 $\mu \mathrm{M})$, AP5 $(40 \mu \mathrm{M})$, and gabazine $(5 \mu \mathrm{M})$, antagonists of AMPA, NMDA, and $\mathrm{GABA}_{\mathrm{A}}$ receptors, respectively, to inhibit fast synaptic transmission in the slice. Blockade of fast synaptic transmission caused a small, but significant, increase in the spontaneous firing of RP3V kisspeptin neurons (from $1.79 \pm 0.31$ to $2.02 \pm 0.36 \mathrm{~Hz} ; t_{(11)}=2.838 ; p=0.016$, 
A

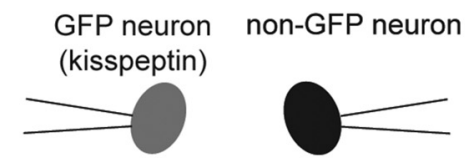

B
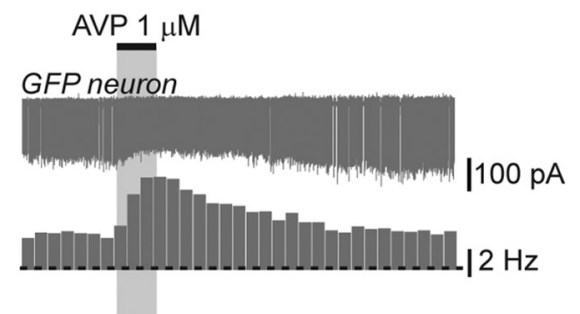

non-GFP neuron
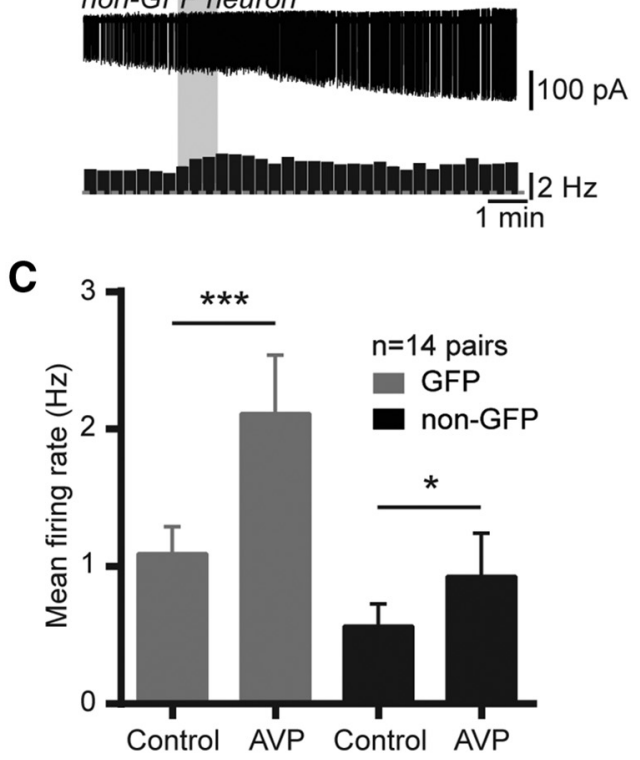

Figure 4. AVP activates kisspeptin and other neurons in the RP3V. $A$, Diagram illustrating the recording configuration. GFP (gray) and non-GFP (black) neurons were recorded simultaneously. $\boldsymbol{B}$, Example paired recording and corresponding rate meters ( $20 \mathrm{~s}$ bins) showing the excitatory effect of AVP (1 $\mu \mathrm{m}$ ) in an RP3V kisspeptin neuron (gray) and a non-GFP RP3V neuron (black). C, Summary bar graphs of the effect of AVP in kisspeptin neurons and in unidentified neurons in the RP3V. ${ }^{*} p<0.05$, Student's $t$ test; ${ }^{* *} p<0.001$, Wilcoxon matched pairs test.

Student's $t$ test; $n=12$ in four mice; data not shown). In the presence of the cocktail, AVP reversibly increased firing in kisspeptin neurons (from $2.02 \pm 0.36$ to $2.81 \pm 0.48 \mathrm{~Hz} ; F_{(2,22)}=$ 9.805; $p<0.001$, repeated measures one-way ANOVA; $n=12$ in four mice; Fig. $3 B, D$ ). We investigated this further by using local pressure applications of AVP in the vicinity of recorded kisspeptin neuron somata. Short (10 s) local applications of AVP $(1 \mu \mathrm{M})$ activated kisspeptin neurons in the presence of the cocktail (Fig. $3 C$ ). On average, AVP puffs caused a significant and reversible increase in RP3V kisspeptin neuron firing (from $1.69 \pm 0.46$ to $3.61 \pm 0.71 \mathrm{~Hz}$; Friedman statistic $=16.80, p<0.001$, Friedman test; $n=10$ in three mice; Fig. $3 D$ ) in the presence of the cocktail.

Together, these findings are consistent with AVP acting through V1aRs to increase firing via a direct mechanism in RP3V kisspeptin neurons.

\section{Non-kisspeptin RP3V neurons are excited by AVP}

As AVP receptors may be expressed in kisspeptin neurons as well as in other neurons in the RP3V (Kalamatianos et al., 2004; Williams et al., 2011), we next performed paired recordings of kisspeptin neurons and non-GFP neurons in the RP3V (Fig. 4A). Ten of 14 kisspeptin neurons $(71 \%)$ increased their firing in response to $\operatorname{AVP}(0.3-1 \mu \mathrm{M})$ and 6 of 14 non-GFP neurons (43\%) were excited by AVP (Fig. 4B). On average, AVP significantly increased spontaneous firing in kisspeptin neurons (from $1.09 \pm 0.20$ to $2.11 \pm 0.43 \mathrm{~Hz} ; 89 \mathrm{~W} ; p<0.001$, Wilcoxon test) and in non-GFP neurons (from $0.56 \pm 0.16$ to $0.93 \pm 0.31 \mathrm{~Hz} ; t_{(13)}=2.277 ; p=$ 0.04 , Student's $t$ test; Fig. $4 C$ ), indicating that the excitatory effect of AVP is not exclusive to kisspeptin neurons in the RP3V.

\section{AVP increases $\left[\mathrm{Ca}^{2+}\right]_{\mathrm{i}}$ in the majority of RP3V kisspeptin neurons}

Single-cell electrophysiology enabled us to determine that AVP directly acts at RP3V kisspeptin neurons to increase their action potential firing. We next sought to examine the effects of AVP on multiple kisspeptin neurons simultaneously. To do this, we generated a mouse model expressing the genetically encoded calcium indicator GCaMP3 (Tian et al., 2009) in kisspeptin neurons (Kiss-GCaMP3). Similar to Kiss-GFP mice, this line was generated from knock-in kisspeptin-IRES-Cre mice that drive reporter expression to RP3V kisspeptin neurons with high efficiency and high selectivity (Mayer et al., 2010; de Croft et al., 2012; Piet et al., 2015). Accordingly, GCaMP3 fluorescence was detected in the RP3V and ARN in exactly the same manner as GFP in Kiss-GFP mice.

Forty-five GCaMP3-expressing RP3V kisspeptin neurons (5.4 \pm 0.7 neurons per slice; range, $4-9$ neurons; eight slices from five diestrous mice) were imaged by epifluorescence (Fig. $5 \mathrm{~A}$ ). Most of these neurons $(>90 \%)$ displayed spontaneous $\left[\mathrm{Ca}^{2+}\right]_{\mathrm{i}}$ fluctuations (as determined by spontaneous changes in relative fluorescence; Fig. 5A). We performed simultaneous cell-attached and $\left[\mathrm{Ca}^{2+}\right]_{\mathrm{i}}$ recordings in seven additional GCaMP3-expressing $\mathrm{RP} 3 \mathrm{~V}$ neurons (four slices from two mice). This revealed that sustained changes in action potential firing, such as those seen in bursting neurons, were associated with discrete transient increases in GCaMP3 fluorescence in RP3V kisspeptin neurons. Single spikes, on the other hand, were not always associated with changes in GCaMP3 fluorescence (Fig. 5B).

To determine whether changes in $\left[\mathrm{Ca}^{2+}\right]_{\mathrm{i}}$ could be evoked by bath-applied drugs in GCaMP3-expressing RP3V kisspeptin neurons, we challenged slices with the glutamate receptor agonist AMPA, which is expected to depolarize RP3V kisspeptin neurons and cause calcium entry. A 1 min bath application of AMPA (30 $\mu \mathrm{M}$ ) elicited large rises in GCaMP3 fluorescence in RP3V kisspeptin neurons (Fig. 5C,D). All kisspeptin neurons recorded increased their fluorescence reversibly in response to AMPA (from $-0.08 \pm 0.01 \%$ to $10.38 \pm 1.05 \% \Delta F / F$; Friedman statistic $=64.58 ; p<0.001$, Friedman test; Fig. $5 E)$, showing that agonist-induced increases in $\left[\mathrm{Ca}^{2+}\right]_{\mathrm{i}}$ could be detected in kisspeptin neurons.

We next tested the effect of AVP on $\left[\mathrm{Ca}^{2+}\right]_{\mathrm{i}}$ in RP3V kisspeptin neurons. Bath application of AVP $(1 \mu \mathrm{M})$ reversibly increased $\left[\mathrm{Ca}^{2+}\right]_{\mathrm{i}}$ in multiple RP3V kisspeptin neurons (Fig. 6A,B). On average, AVP significantly and reversibly increased $\left[\mathrm{Ca}^{2+}\right]_{\mathrm{i}}$ (from $-0.04 \pm 0.03 \%$ to $1.04 \pm 0.19 \% \Delta F / F$; Friedman statistic $=48.84 ; p<0.001$, Friedman test; Fig. $6 C)$ in diestrous mice. The great majority $(82.2 \%)$ of RP3V kisspeptin neurons responded to AVP with an elevation in $\left[\mathrm{Ca}^{2+}\right]_{\mathrm{i}}$.

We next examined the mechanism through which AVP increased $\left[\mathrm{Ca}^{2+}\right]_{\mathrm{i}}$ in RP3V kisspeptin neurons. In these experiments, AVP was applied twice at 30-45 min intervals, with the second application in the presence of a cocktail of antagonists. In control experiments where AVP was applied twice in aCSF, we observed that kisspeptin neurons responded to both AVP applications, although responses to the second application were sig- 


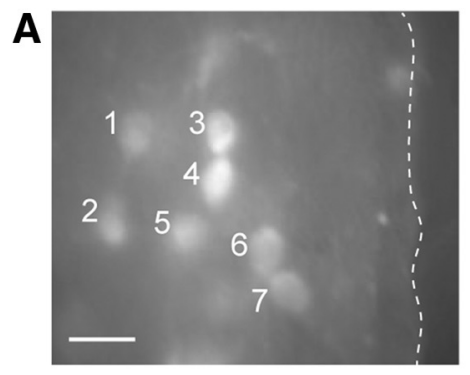

B
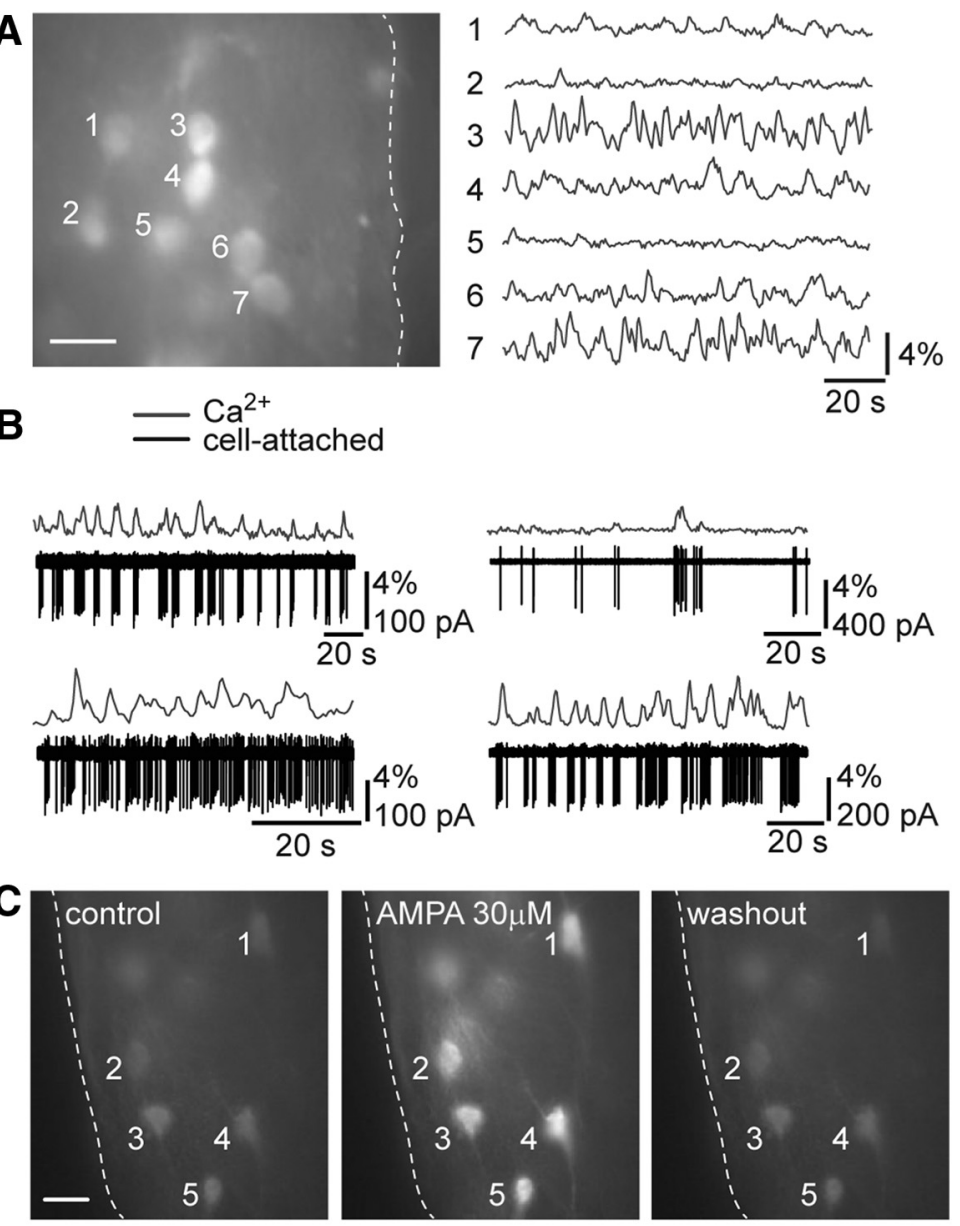
$20 \mathrm{~s}$

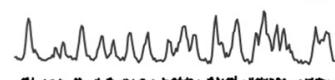
$\left.\right|_{100} ^{4 \%} \mathrm{pA}$
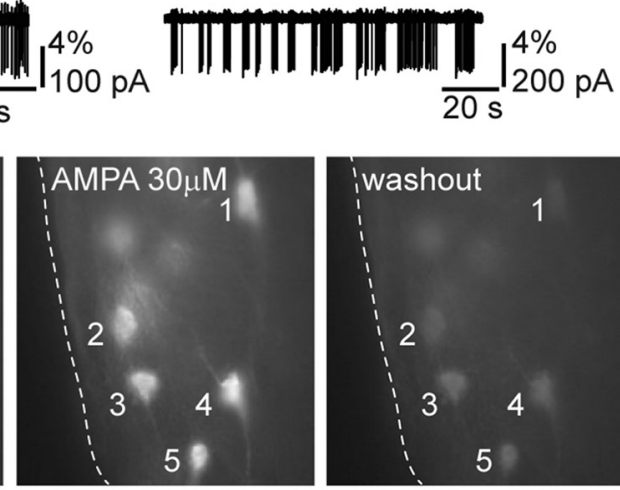

D

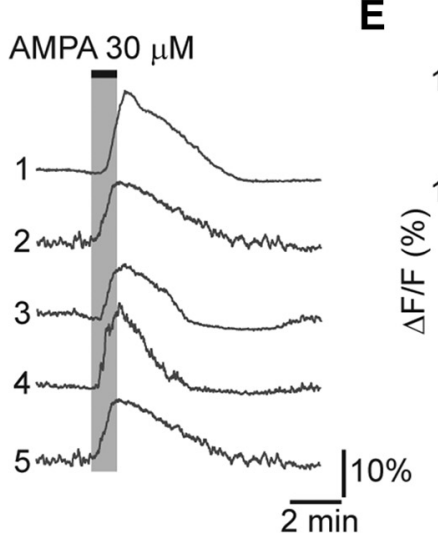

$n=45$ neurons, 8 slices

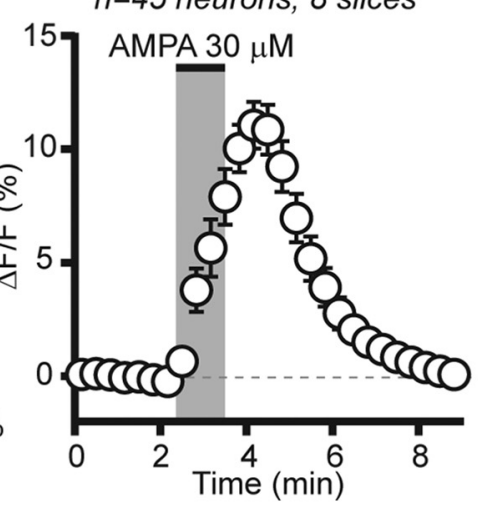

Figure 5. Imaging of $\left[\mathrm{Ca}^{2+}\right]_{\mathrm{i}}$ fluctuations in RP3V kisspeptin neurons from Kiss-GCaMP3 mice. $A$, Average projection image (over 2 min; left) of a brain slice including the RP3V obtained from a diestrous Kiss-GCaMP3 mouse. Numbers indicate GCaMP3-expressing kisspeptin neuron somata selected for fluorescence measurements. The dashed line outlines the border of the third ventricle. Scale bar, $10 \mu \mathrm{m}$. Time-series imaging revealed spontaneous fluctuations in $\left[\mathrm{Ca}^{2+}\right]_{\mathrm{i}}$ in RP3V kisspeptin neurons (right). $\boldsymbol{B}$, Dual electrophysiological and $\left[\mathrm{Ca}^{2+}\right]_{\mathrm{i}}$ recordings from four different RP3V GCaMP3-expressing kisspeptin neurons illustrate that sustained changes in action potential firing elicit large calcium transients in kisspeptin neurons, whereas single spikes were difficult to resolve with calcium imaging. C, Average projection images ( $1 \mathrm{~min}$ ) of a diestrous RP3V slice before, immediately following, and $>10$ min after the bath application of AMPA (30 $\mu \mathrm{m})$. Scale bar, $10 \mu \mathrm{m}$. D, The corresponding traces show the time course of fluorescence in GCaMP3-expressing kisspeptin neurons. AMPA elicitedlarge fluorescencetransientsinevery kisspeptinneuron. E, Averagetimecourse of GCaMP3 fluorescencechanges in responseto AMPAin RP3V kisspeptin neurons from diestrous mice. Each data point represents relative GCaMP3 fluorescence (20 s bins) averaged across multiple neurons. $\mu \mathrm{M})$ to inhibit all synaptic transmission in the slice, AVP continued to increase $\left[\mathrm{Ca}^{2+}\right]_{\mathrm{i}}$ in $\mathrm{RP} 3 \mathrm{~V}$ kisspeptin neurons (from $-0.03 \pm 0.01 \%$ to $0.96 \pm 0.41 \%$ $\Delta F / F$; Friedman statistic $=17.86 ; p<$ 0.001 , Friedman test; $n=29$ neurons in five slices from four mice; Fig. $6 E$ ), confirming that the effect of AVP is direct.

We tested whether AVP-induced increases in $\left[\mathrm{Ca}^{2+}\right]_{\mathrm{i}}$ resulted from calcium entry through voltage-gated calcium channels (VGCCs) or from calcium mobilization from intracellular stores. To do this, the antagonist cocktail was supplemented with $\mathrm{CdCl}_{2}(100 \mu \mathrm{M})$ and $\mathrm{NiCl}_{2}(200 \mu \mathrm{M})$ to block VGCCs. Remarkably, in the presence of $\mathrm{Cd}^{2+}$ and $\mathrm{Ni}^{2+}$, AVP-induced increases in $\left[\mathrm{Ca}^{2+}\right]_{\mathrm{i}}$ were completely absent, and only the time-dependent fluorescence decay was observed (from $-0.09 \pm 0.01 \%$ to $-0.63 \pm 0.08 \% \Delta F / F$; Friedman statistic $=86.00 ; p<0.001$, Friedman test; $n=$ 43 neurons in five slices from five mice; Fig. $6 F$ ). We then examined the contribution of calcium release from internal stores in AVP-induced responses using cyclopiazonic acid (CPA) at $30 \mu \mathrm{M}$, a concentration that prevents store-dependent calcium signals in GnRH neurons (Constantin et al., 2010; Lee et al., 2010; Iremonger and Herbison, 2012). In the presence of the cocktail supplemented with CPA, AVP increased $\left[\mathrm{Ca}^{2+}\right]_{i}$ in RP3V kisspeptin neurons (from $-0.02 \pm$ $0.01 \%$ to $2.42 \pm 0.39 \% \Delta F / F$; Friedman statistic $=51.24 ; p<0.001$, Friedman test; $n=45$ neurons in five slices from four mice; Fig. 6G). To compare the effect of AVP in the different conditions, we measured the ratio of the second response to the first response. Response ratios differed significantly in the different conditions [Kruskal-Wallis $(\mathrm{K}-\mathrm{W})$ statistic $=$ $54.54, p<0.001$, K-W test], being similar in the presence of the cocktail $(0.75 \pm$ 0.32) or in the presence of the cocktail with CPA $(0.86 \pm 0.20)$ to the response ratio in aCSF $(0.56 \pm 0.07 ; p>0.05$, Dunn's post-tests) but significantly lower in the presence of the cocktail with $\mathrm{Cd}^{2+}$ and $\mathrm{Ni}^{2+}(-0.40 \pm 0.29 ; p<0.001$, Dunn's post-tests) than in all the other conditions. Together, these results indicate that AVP-induced increases in $\left[\mathrm{Ca}^{2+}\right]_{\mathrm{i}}$ result predominantly from calcium influx through VGCCs, while intracellular calcium stores appear not to be involved. nificantly smaller (net effect: AVP $12.91 \pm 0.36$ vs AVP 2, $1.78 \pm$ $0.26 \% \Delta F / F ;-789 \mathrm{~W} ; p<0.001$, Wilcoxon test; $n=41$ neurons in five slices from five mice; Fig. $6 D)$. In the presence of a cocktail of CNQX (10 $\mu \mathrm{M})$, AP5 (40 $\mu \mathrm{M})$, gabazine $(5 \mu \mathrm{M})$, and TTX $(0.5$
RP3V kisspeptin neuron response to AVP is estrogen dependent In OVX-treated rodent models, the timing of the LH surge and/or the processing of timing signals are dependent upon circulating estrogen levels (Legan et al., 1975; Terasawa et al., 1979). 


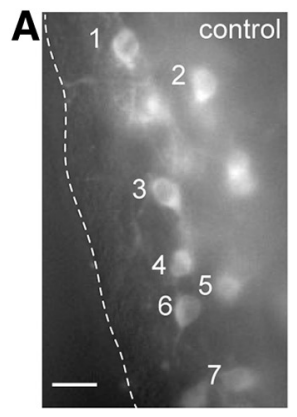

B

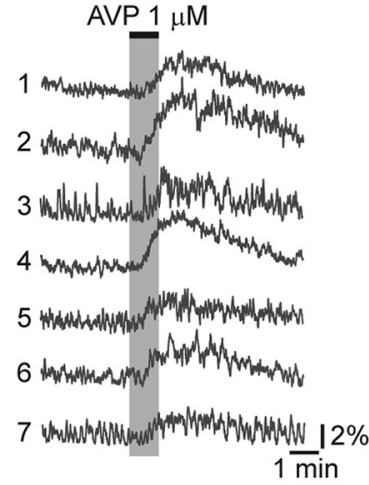

D in aCSF

$n=41$ neurons, 5 slices

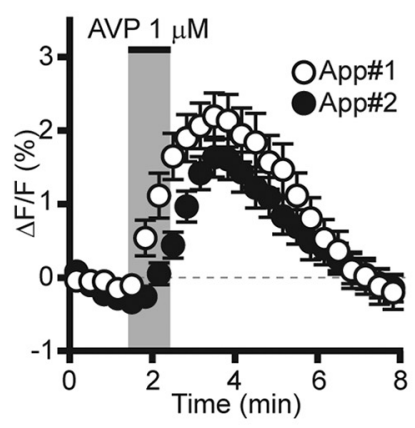

$\mathbf{F}$ in cocktail with $\mathrm{Cd}^{2+}+\mathrm{Ni}^{2+}$ $n=43$ neurons, 5 slices

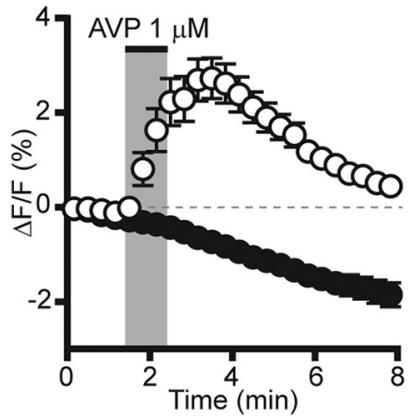

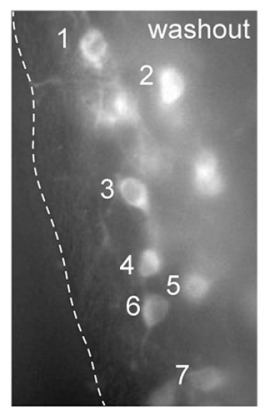

C

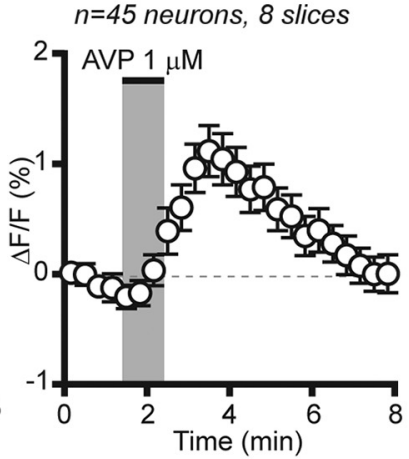

E in cocktail $n=29$ neurons, 5 slices

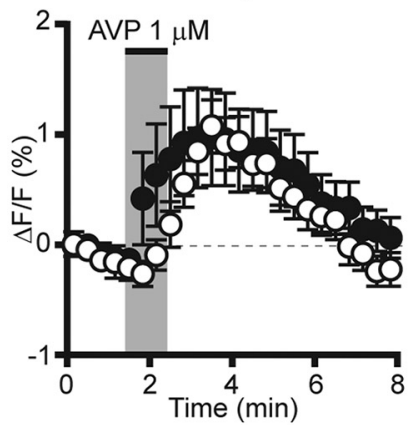

G in cocktail with $C P A$ $n=45$ neurons, 5 slices

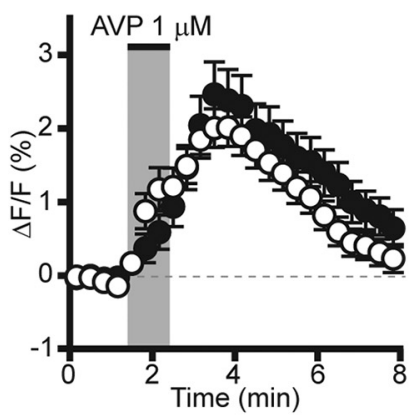

Figure 6. AVP increases $\left[\mathrm{Ca}^{2+}\right]_{\mathrm{i}}$ in RP3V kisspeptin neurons. $A$, Average projection images (1 $\mathrm{min}$ ) of an RP3V slice before, immediately after, and $5 \mathrm{~min}$ after the application of AVP (1 $\mu \mathrm{m})$. Scale bar, $10 \mu \mathrm{m}$. $\boldsymbol{B}$, Corresponding traces showing that AVP reversibly increased fluorescence in multiple RP3V kisspeptin neurons. $\boldsymbol{C}$, Average time course of GCaMP3 fluorescence changes in response to AVP in RP3V kisspeptin neurons from diestrous mice. $D-G$, Average time course of RP3V kisspeptin neuron $\left[\mathrm{Ca}^{2+}\right]_{i}$ responses to two successive applications of AVP (App\#1 and App\#2) in aCSF (D), in the presence of a cocktail including a sodium channel inhibitor, and $\mathrm{GABA}_{\mathrm{A}}, \mathrm{AMPA}$, and NMDA receptor antagonists $(\boldsymbol{E})$, in the cocktail supplemented with $\mathrm{Cd}^{2+}$ and $\mathrm{Ni}^{2+}(\boldsymbol{F})$ and in the cocktail supplemented with CPA (G; cocktail contained TTX, CNQX, AP5, and gabazine). Each data point represents the relative GCaMP3 fluorescence (20 s bins) averaged across multiple neurons in $\mathbf{C}-\mathbf{G}$.
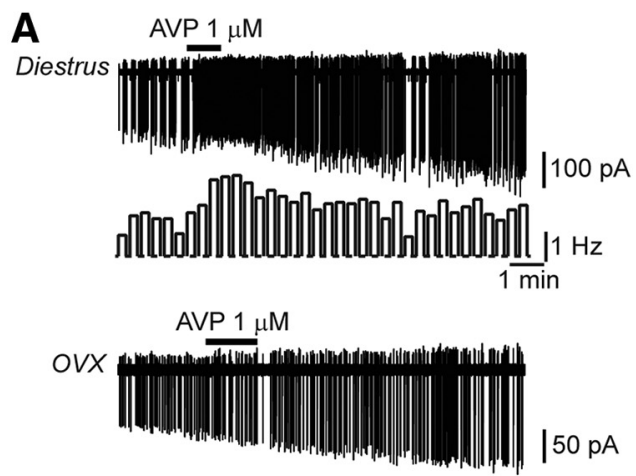

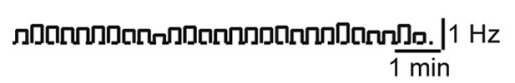

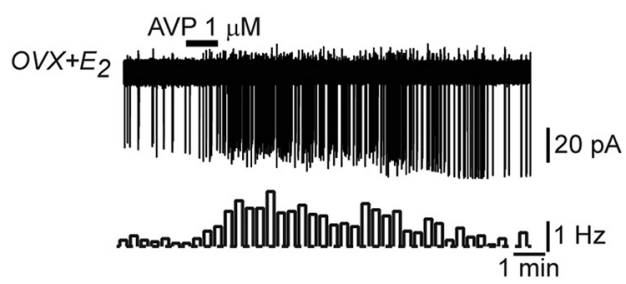

B

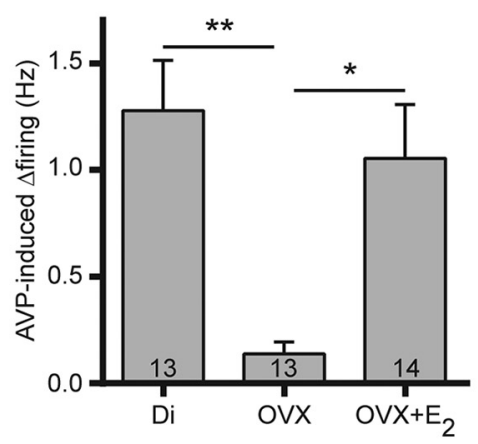

Figure 7. Circulating estradiol exerts a permissive effect on AVP-induced excitation of RP3V kisspeptin neurons. $A$, Sample traces and rate meters (20 s bins) illustrating the effect of AVP on RP3V kisspeptin neuron firing in diestrous (Di), ovariectomized (OVX), and estradiol-treated ovariectomized $\left(O V X+E_{2}\right)$ mice. The excitatory effect of AVP is lost in ovariectomized mice and is restored by in vivo $17 \beta$-estradiol treatment. $B$, Bar graph summarizing the net effect of AVP in diestrous, ovariectomized, and estadiol-treated ovariectomized $\left(\mathrm{OVX}+\mathrm{E}_{2}\right)$ mice. ${ }^{*} p<0.05$ and ${ }^{* *} p<0.01, \mathrm{~K}-\mathrm{W}$ test with Dunn's post-tests.

In addition, evidence suggests that the RP3V is a likely site for where circadian cues and estrogen signals are integrated (Watson et al., 1995; de la Iglesia et al., 1995; Vida et al., 2010; Williams et al., 2011). As such, we next examined whether AVP signaling in RP3V kisspeptin neurons was dependent upon circulating estrogen levels by assessing AVP-induced excitation in diestrous, ovariectomized, and $17 \beta$-estradiol-treated ovariectomized mice. AVP $(1 \mu \mathrm{M})$ caused large $(\sim 100 \%)$ increases in firing (from $1.20 \pm 0.34$ to $2.48 \pm 0.40 \mathrm{~Hz}$; Friedman statistic $=12.92 ; p=$ 0.002 , Friedman test; $n=13$ in four mice) in 11 of 13 diestrous kisspeptin neurons, but only a small $(\sim 25 \%)$ increase (from $0.51 \pm 0.14$ to $0.64 \pm 0.17 \mathrm{~Hz} ; F_{(2,24)}=4.27 ; p=0.026$, repeatedmeasures one-way ANOVA; $n=13$ in four mice) in 4 of 13 OVX kisspeptin neurons ( $p=0.02$ vs diestrus, Fisher's exact test). This is likely due to alterations in AVP signaling in OVX kisspeptin neurons rather than to diminished excitability as RP3V kisspeptin neurons could still increase their spontaneous firing in response to bath applications of AMPA in ovariectomized mice (from $0.61 \pm 0.43$ to $3.30 \pm 0.74 \mathrm{~Hz}$ ) despite remaining unre- 

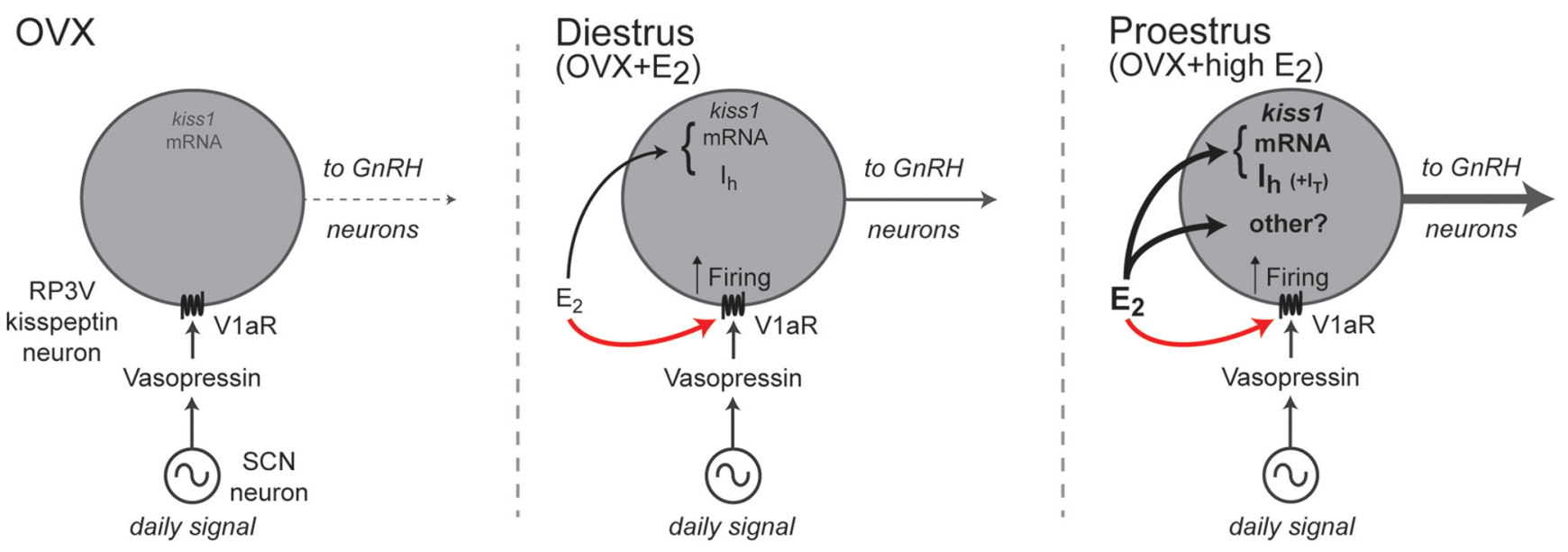

Figure 8. Model for integration of circadian and estradiol signals in RP3V kisspeptin neurons. SCN AVP neurons project to RP3V kisspeptin neurons, providing time of day-related cues (daily signal) to these neurons. In ovariectomized (OVX) mice (left), AVP has minimal effects on RP3V kisspeptin neuron firing. In intact females, circulating estradiol has a permissive effect in enabling AVP signaling to alter firing in RP3V kisspeptin neurons. This remains constant across the estrous cycle (red arrow, middle and right). Elevated proestrous estradiol levels or high estrogen treatment of ovariectomized mice (black arrows) upregulates kiss 1 gene expression and specific ion currents (e.g. $/ I_{\mathrm{h}}$ and the $I_{\mathrm{T}}$ ), and may promote yet-to-be identified effects on RP3V kisspeptin neuron function (other?). These downstream estradiol-dependent alterations likely enable efficient integration of the SCN AVP input to enhance the final output of RP3V kisspeptin cells to GnRH neurons at the time of the LH surge (right).

sponsive to AVP (from $0.37 \pm 0.20$ to $0.31 \pm 0.15 \mathrm{~Hz} ; n=3$; data not shown), which is consistent with our previous observations that OVX does not alter overall excitability in these neurons (Piet et al., 2013). In 17 $\beta$-estradiol-treated ovariectomized mice, AVPinduced increases in firing were seen in 11 of 14 kisspeptin neurons ( $p=0.02$, vs ovariectomized neurons, Fisher's exact test) and were restored to diestrous levels ( $\sim 75 \%$; from $1.41 \pm 0.44$ to $2.47 \pm 0.45 \mathrm{~Hz} ; F_{(2,26)}=17.80 ; p<0.001$, repeated-measures one-way ANOVA; $n=14$ in four mice; Fig. $7 A$ ). The magnitude of the net effect of AVP significantly differed among the three mouse groups, with RP3V kisspeptin neurons displaying significantly larger increases in diestrous $(1.28 \pm 0.24 \mathrm{~Hz})$ and $17 \beta$ estradiol-treated ovariectomized mice $(1.06 \pm 0.25 \mathrm{~Hz})$ compared with ovariectomized mice $(0.14 \pm 0.06 \mathrm{~Hz}$; K-W statistic $=12.56 ; p=0.002, \mathrm{~K}-\mathrm{W}$ test; Fig. $7 B)$.

These results show that the effects of AVP on RP3V kisspeptin neurons in intact mice are critically dependent upon circulating estradiol levels.

\section{Discussion}

Using kisspeptin-GFP and kisspeptin-GCaMP3 mouse models, we report here that AVP exerts a direct, V1aR-dependent, excitation of most RP3V kisspeptin neurons in female mice. Unexpectedly, the effects of AVP on kisspeptin neurons were not found to depend upon time of day or the stage of the estrous cycle examined. Further, studies in ovariectomized mice revealed that estrogen exerts a permissive influence on AVP signaling in these neurons. These observations indicate that estradiol does not gate AVP signaling to a specific time window in relation to the generation of the GnRH surge but rather acts in a permissive manner to simply enable AVP modulation of kisspeptin neurons (Fig. 8).

\section{AVP signaling is critical for $\mathrm{SCN}$ regulation of the $\mathrm{GnRH}$ neuronal network}

There is substantial evidence implicating SCN AVP afferents in the timing of the preovulatory GnRH surge that evokes the LH surge. Lesions of the SCN and genetic impairment of the circadian clockmechanism result in a failure of the $\mathrm{GnRH}$ neuronal network to generate a preovulatory surge (Stetson and Watson-Whitmyre, 1976; Wiegand et al., 1980; Miller et al., 2004). Anatomically, the
SCN provides well characterized direct neural connections within the GnRH neuronal network, including a projection from AVP-producing SCN neurons to RP3V kisspeptin neurons (Watson et al., 1995; de la Iglesia et al., 1995; Van der Beek et al., 1997; Vida et al., 2010; Williams et al., 2011). Moreover, the AVP-rich dorsomedial subdivision of the SCN has been shown to control the timing of Kiss 1 gene expression in the RP3V and the timing of the GnRH/LH surge (Smarr et al., 2012). In agreement with this, AVP central injections restore the $\mathrm{LH}$ surge in rodents with SCN lesions or with genetic impairments of circadian rhythms (Palm et al., 1999; Miller et al., 2006), although studies with V1R antagonists have been less consistent in their findings (Funabashi et al., 1999; Palm et al., 2001; Miller et al., 2006).

Our results provide a cellular mechanism through which AVP exerts its effects on the GnRH neuronal network as we show that AVP dose-dependently increases the firing rate of RP3V kisspeptin neurons and that $>80 \%$ of kisspeptin neurons in KissGCaMP3 mice are activated directly by AVP. In addition, our experiments revealed that AVP-induced $\left[\mathrm{Ca}^{2+}\right]_{\mathrm{i}}$ increases were predominantly mediated by calcium influx through VGCCs in RP3V kisspeptin neurons, as was previously reported in AVPsensitive supraoptic nucleus neurons (Sabatier et al., 1997), but not via calcium release from intracellular stores. Together, these findings indicate that, by using AVP as a neurotransmitter, SCN neurons have considerable potential to coordinate the activity of most kisspeptin neurons in the RP3V, providing a powerful mechanism to orchestrate the activity of the downstream GnRH neurons.

\section{AVP signaling in RP3V kisspeptin neurons is constant over the diurnal cycle}

Prior studies suggested that the GnRH neuronal network exhibited selective temporal sensitivity to AVP. The administration of exogenous AVP into the preoptic area was found to potentiate the LH surge in female rats but only if administered toward the end of the light period (Palm et al., 2001). Furthermore, at a cellular level, it was found that V1aR gene (Avplar) expression in the $\mathrm{RP} 3 \mathrm{~V}$ was circadian, with the highest levels occurring at the end of the subjective day (Smarr et al., 2013). Together, these observations suggested that circadian variations in $\mathrm{V} 1 \mathrm{aR}$ function 
within RP3V kisspeptin neurons themselves might help encode the time of day. However, with the ability to examine AVP signaling directly, we find that AVP activates RP3V kisspeptin neurons similarly just before the expected time of the LH surge (ZT10) and hours before its generation (ZT4-ZT6). Furthermore, responsiveness to AVP is similar in diestrous females during the day (ZT4-ZT6) and during the night (ZT16-ZT17). Altogether, this suggests that circadian variations in Avplar expression in the RP3V are not associated with alterations in AVP signaling in RP3V kisspeptin neurons. This is reminiscent of findings in the hamster where central AVP administration activates c-Fos expression in RP3V kisspeptin neurons both in the morning (ZT1) and the afternoon (ZT11; Williams et al., 2011). Either the changes reported in Avplar mRNA are not sufficient to have an impact on AVP signaling in kisspeptin neurons or they occur in RP3V cells other than kisspeptin neurons. Indeed, we show here that kisspeptin neurons are only one population of RP3V neurons that respond to AVP. Alternatively, our findings might reflect species differences between mice and rats in the diurnal regulation of Avplar expression in the RP3V.

Overall, the present observations imply that transmission of the daily circadian signal to kisspeptin neurons is not dependent upon variations in AVP receptor signaling, but, more likely, upon AVP release itself. Expression of the Avp gene in the rodent SCN is low during the night and increases during the day (Uhl and Reppert, 1986; Dardente et al., 2004), and higher rates of AVP release within the SCN are seen during the day (Kalsbeek et al., 1995), making it likely that AVP release in the vicinity of RP3V kisspeptin neurons is also diurnally regulated.

\section{Estradiol is permissive for AVP signaling in RP3V kisspeptin neurons}

Previous studies have implied that fluctuating levels of estradiol during the ovarian cycle are responsible for gating the daily signal that activates RP3V kisspeptin neurons and the GnRH neuronal network specifically on the afternoon of proestrus. For example, Avplar expression in the RP3V (Kalamatianos et al., 2004) and its circadian fluctuations (Smarr et al., 2013) depend on circulating estrogen levels, as do circadian changes in c-Fos and Kiss1 mRNA expression in RP3V kisspeptin neurons (Robertson et al., 2009; Williams et al., 2011). However, these models are based on observations in estradiol-treated ovariectomized females, in which fluctuations in circulating estrogen concentrations are virtually abolished. Whether such observations faithfully reflect variations in AVP signaling in RP3V kisspeptin neurons across the natural estrous cycle has remained unclear. Unexpectedly, we found here that AVP has the same excitatory actions on RP3V kisspeptin neurons in proestrus (when the GnRH surge is generated) and in diestrus, even in experiments carried out just before the end of the light cycle, around the time the LH surge is generated. We show, however, that AVP signaling in RP3V kisspeptin neurons is almost completely abolished in ovariectomized mice and is fully recovered by estradiol replacement. Thus, there seems to be little question that circulating estradiol is critical for AVP signaling in kisspeptin neurons, but that it acts in a permissive manner rather than by cyclically modulating AVP signaling efficacy across the ovarian cycle (Fig. 8).

\section{Implications for the circadian control of the preovulatory GnRH surge}

The findings of this study indicate that the steroid-sensitive circadian gate within the GnRH neuronal network is not encoded by AVP signaling at the RP3V kisspeptin neurons (Fig. 8). Neverthe- less, it is very clear that the fluctuating levels of estradiol through the 4-5 d ovarian cycle effectively gate the efficacy of the circadian input to only proestrus. As such, the gating by estradiol must occur independently of variations in AVP receptor signaling in RP3V kisspeptin neurons. The high circulating levels of estradiol in proestrus, or ovariectomized mice treated with high estrogen, have been shown to increase Kiss 1 gene expression (Smith et al., 2006) and also upregulate specific ionic currents such as the hyperpolarization-activated cation current $\left(I_{\mathrm{h}}\right)$ and the lowthreshold transient calcium current $\left(I_{\mathrm{T}}\right)$ in RP3V kisspeptin neurons (Piet et al., 2013; Zhang et al., 2013). Upregulation of these ionic currents would be envisaged to counteract hyperpolarization and/or isolate RP3V kisspeptin neurons from background synaptic activity (Piet et al., 2015), thereby favoring the transmission of AVP-mediated signals in these cells on the day the GnRH surge is generated. It is important to note that because the key synaptic inputs involved in the generation of the surge are likely absent in brain slices (Piet et al., 2015), our experiments did not address the mechanisms proposed above, but rather only interrogated AVP signaling in RP3V kisspeptin neurons.

Thus, we speculate that a high estradiol level primes independent downstream molecular and biophysical events in RP3V kisspeptin neurons so that the daily SCN AVP signal can recruit these cells to a high level of activity once every ovarian cycle to activate the final output GnRH neurons (Fig. 8). Notably, we have previously shown that RP3V kisspeptin neurons must be activated at $>5-10 \mathrm{~Hz}$ before they will release sufficient kisspeptin onto GnRH neurons to activate their action potential firing (Liu et al., 2011). In this scenario, the daily AVP signal would cause significant kisspeptin release on GnRH neurons only when RP3V kisspeptin neurons had previously been exposed to the high proestrous estradiol levels, enabling the appropriate processing of the daily SCN signal (Fig. 8).

To conclude, we report here that AVP activates the majority of RP3V kisspeptin neurons in a direct manner. As AVP can excite RP3V kisspeptin neurons during both day and night, and across the ovarian cycle, the gating of the SCN-triggered $\mathrm{GnRH}$ surge only to proestrus must occur independently of V1aR signaling in these cells. While not dynamically modulating responsiveness to AVP in kisspeptin neurons across the ovarian cycle, estradiol is, nevertheless, critical in permitting the daily SCN-derived AVP input to kisspeptin neurons.

\section{References}

Bronson FH (1981) The regulation of luteinizing hormone secretion by estrogen: relationships among negative feedback, surge potential, and male stimulation in juvenile, peripubertal, and adult female mice. Endocrinology 108:506-516. CrossRef Medline

Busnelli M, Bulgheroni E, Manning M, Kleinau G, Chini B (2013) Selective and potent agonists and antagonists for investigating the role of mouse oxytocin receptors. J Pharmacol Exp Ther 346:318-327. CrossRef Medline

Christian CA, Moenter SM (2008) Critical roles for fast synaptic transmission in mediating estradiol negative and positive feedback in the neural control of ovulation. Endocrinology 149:5500-5508. CrossRef Medline

Clarkson J, d'Anglemont de Tassigny X, Moreno AS, Colledge WH, Herbison AE (2008) Kisspeptin-GPR54 signaling is essential for preovulatory gonadotropin-releasing hormone neuron activation and the luteinizing hormone surge. J Neurosci 28:8691-8697. CrossRef Medline

Constantin S, Jasoni CL, Wadas B, Herbison AE (2010) Gamma-aminobutyric acid and glutamate differentially regulate intracellular calcium concentrations in mouse gonadotropin-releasing hormone neurons. Endocrinology 151:262-270. CrossRef Medline

Dardente H, Menet JS, Challet E, Tournier BB, Pévet P, Masson-Pévet M (2004) Daily and circadian expression of neuropeptides in the suprachi- 
asmatic nuclei of nocturnal and diurnal rodents. Brain Res Mol Brain Res 124:143-151. CrossRef Medline

de Croft S, Piet R, Mayer C, Mai O, Boehm U, Herbison AE (2012) Spontaneous kisspeptin neuron firing in the adult mouse reveals marked sex and brain region differences but no support for a direct role in negative feedback. Endocrinology 153:5384-5393. CrossRef Medline

de la Iglesia HO, Schwartz WJ (2006) Minireview: timely ovulation: circadian regulation of the female hypothalamo-pituitary-gonadal axis. Endocrinology 147:1148-1153. CrossRef Medline

de la Iglesia HO, Blaustein JD, Bittman EL (1995) The suprachiasmatic area in the female hamster projects to neurons containing estrogen receptors and GnRH. Neuroreport 6:1715-1722. CrossRef Medline

Edelstein A, Amodaj N, Hoover K, Vale R, Stuurman N (2010) Computer control of microscopes using $\mu$ Manager. Curr Protoc Mol Biol Chapter 14:Unit14.20. CrossRef Medline

Everett JW, Sawyer CH (1950) A 24-hour periodicity in the "LH-release apparatus" of female rats, disclosed by barbiturate sedation. Endocrinology 47:198-218. CrossRef Medline

Funabashi T, Aiba S, Sano A, Shinohara K, Kimura F (1999) Intracerebroventricular injection of arginine-vasopressin V1 receptor antagonist attenuates the surge of luteinizing hormone and prolactin secretion in proestrous rats. Neurosci Lett 260:37-40. CrossRef Medline

Herbison AE (2008) Estrogen positive feedback to gonadotropin-releasing hormone $(\mathrm{GnRH})$ neurons in the rodent: the case for the rostral periventricular area of the third ventricle (RP3V). Brain Res Rev 57:277-287. CrossRef Medline

Iremonger KJ, Herbison AE (2012) Initiation and propagation of action potentials in gonadotropin-releasing hormone neuron dendrites. J Neurosci 32:151-158. CrossRef Medline

Kalamatianos T, Kalló I, Goubillon ML, Coen CW (2004) Cellular expression of V1a vasopressin receptor mRNA in the female rat preoptic area: effects of oestrogen. J Neuroendocrinol 16:525-533. CrossRef Medline

Kalsbeek A, Buijs RM, Engelmann M, Wotjak CT, Landgraf R (1995) In vivo measurement of a diurnal variation in vasopressin release in the rat suprachiasmatic nucleus. Brain Res 682:75-82. CrossRef Medline

Kriegsfeld LJ, Silver R (2006) The regulation of neuroendocrine function: timing is everything. Horm Behav 49:557-574. CrossRef Medline

Lee K, Duan W, Sneyd J, Herbison AE (2010) Two slow calcium-activated afterhyperpolarization currents control burst firing dynamics in gonadotropin-releasing hormone neurons. J Neurosci 30:6214-6224. CrossRef Medline

Legan SJ, Karsch FJ (1975) A daily signal for the LH surge in the rat. Endocrinology 96:57-62. CrossRef Medline

Legan SJ, Coon GA, Karsch FJ (1975) Role of estrogen as initiator of daily LH surges in the ovariectomized rat. Endocrinology 96:50-56. CrossRef Medline

Li JD, Hu WP, Zhou QY (2012) The circadian output signals from the suprachiasmatic nuclei. Prog Brain Res 199:119-127. CrossRef Medline

Liu X, Porteous R, d'Anglemont de Tassigny X, Colledge WH, Millar R, Petersen SL, Herbison AE (2011) Frequency-dependent recruitment of fast amino acid and slow neuropeptide neurotransmitter release controls gonadotropin-releasing hormone neuron excitability. J Neurosci 31: 2421-2430. CrossRef Medline

Lowbridge J, Manning M, Haldar J, Sawyer WH (1977) Synthesis and some pharmacological properties of [4-threonine, 7-glycine] oxytocin, [1-(L-2hydroxy-3-mercaptopropanoic acid), 4-threonine, 7-glycine] oxytocin (hydroxy[Thr4, Gly7]oxytocin), and [7-glycine] oxytocin, peptides with high oxytocic-antidiuretic selectivity. J Med Chem 20:120-123. CrossRef Medline

Manning M, Misicka A, Olma A, Bankowski K, Stoev S, Chini B, Durroux T, Mouillac B, Corbani M, Guillon G (2012) Oxytocin and vasopressin agonists and antagonists as research tools and potential therapeutics. J Neuroendocrinol 24:609-628. CrossRef Medline

Mayer C, Acosta-Martinez M, Dubois SL, Wolfe A, Radovick S, Boehm U, Levine JE (2010) Timing and completion of puberty in female mice depend on estrogen receptor alpha-signaling in kisspeptin neurons. Proc Natl Acad Sci U S A 107:22693-22698. CrossRef Medline

Miller BH, Olson SL, Turek FW, Levine JE, Horton TH, Takahashi JS (2004) Circadian clock mutation disrupts estrous cyclicity and maintenance of pregnancy. Curr Biol 14:1367-1373. CrossRef Medline

Miller BH, Olson SL, Levine JE, Turek FW, Horton TH, Takahashi JS (2006) Vasopressin regulation of the proestrous luteinizing hormone surge in wild-type and Clock mutant mice. Biol Reprod 75:778-784. CrossRef Medline

Moore RY, Eichler VB (1972) Loss of a circadian adrenal corticosterone rhythm following suprachiasmatic lesions in the rat. Brain Res 42:201206. CrossRef Medline

Owen BM, Bookout AL, Ding X, Lin VY, Atkin SD, Gautron L, Kliewer SA, Mangelsdorf DJ (2013) FGF21 contributes to neuroendocrine control of female reproduction. Nat Med 19:1153-1156. CrossRef Medline

Palm IF, Van Der Beek EM, Wiegant VM, Buijs RM, Kalsbeek A (1999) Vasopressin induces a luteinizing hormone surge in ovariectomized, estradiol-treated rats with lesions of the suprachiasmatic nucleus. Neuroscience 93:659-666. CrossRef Medline

Palm IF, van der Beek EM, Wiegant VM, Buijs RM, Kalsbeek A (2001) The stimulatory effect of vasopressin on the luteinizing hormone surge in ovariectomized, estradiol-treated rats is time-dependent. Brain Res 901: 109-116. CrossRef Medline

Partch CL, Green CB, Takahashi JS (2014) Molecular architecture of the mammalian circadian clock. Trends Cell Biol 24:90-99. CrossRef Medline

Piet R, Boehm U, Herbison AE (2013) Estrous cycle plasticity in the hyperpolarization-activated current $I_{\mathrm{h}}$ is mediated by circulating $17 \beta$ estradiol in preoptic area kisspeptin neurons. J Neurosci 33:1082810839. CrossRef Medline

Piet R, de Croft S, Liu X, Herbison AE (2015) Electrical properties of kisspeptin neurons and their regulation of GnRH neurons. Front Neuroendocrinol 36C:15-27. CrossRef Medline

Robertson JL, Clifton DK, de la Iglesia HO, Steiner RA, Kauffman AS (2009) Circadian regulation of Kiss1 neurons: implications for timing the preovulatory gonadotropin-releasing hormone/luteinizing hormone surge. Endocrinology 150:3664-3671. CrossRef Medline

Sabatier N, Richard P, Dayanithi G (1997) L-, N- and T- but neither P- nor Q-type Ca2 + channels control vasopressin-induced Ca2 + influx in magnocellular vasopressin neurones isolated from the rat supraoptic nucleus. J Physiol 503:253-268. CrossRef Medline

Schneider CA, Rasband WS, Eliceiri KW (2012) NIH Image to ImageJ: 25 years of image analysis. Nat Methods 9:671-675. CrossRef Medline

Smarr BL, Morris E, de la Iglesia HO (2012) The dorsomedial suprachiasmatic nucleus times circadian expression of Kiss1 and the luteinizing hormone surge. Endocrinology 153:2839-2850. CrossRef Medline

Smarr BL, Gile JJ, de la Iglesia HO (2013) Oestrogen-independent circadian clock gene expression in the anteroventral periventricular nucleus in female rats: possible role as an integrator for circadian and ovarian signals timing the luteinising hormone surge. J Neuroendocrinol 25:1273-1279. CrossRef Medline

Smith JT, Popa SM, Clifton DK, Hoffman GE, Steiner RA (2006) Kiss1 neurons in the forebrain as central processors for generating the preovulatory luteinizing hormone surge. J Neurosci 26:6687-6694. CrossRef Medline

Stephan FK, Zucker I (1972) Circadian rhythms in drinking behavior and locomotor activity of rats are eliminated by hypothalamic lesions. Proc Natl Acad Sci U S A 69:1583-1586. CrossRef Medline

Stetson MH, Watson-Whitmyre M (1976) Nucleus suprachiasmaticus: the biological clock in the hamster? Science 191:197-199. CrossRef Medline

Terasawa E, Rodriguez JS, Bridson WE, Wiegand SJ (1979) Factors influencing the positive feedback action of estrogen upon the luteinizing hormone surge in the ovariectomized guinea pig. Endocrinology 104:680-686. CrossRef Medline

Tian L, Hires SA, Mao T, Huber D, Chiappe ME, Chalasani SH, Petreanu L, Akerboom J, McKinney SA, Schreiter ER, Bargmann CI, Jayaraman V, Svoboda K, Looger LL (2009) Imaging neural activity in worms, flies and mice with improved GCaMP calcium indicators. Nat Methods 6:875881. CrossRef Medline

Uhl GR, Reppert SM (1986) Suprachiasmatic nucleus vasopressin messenger RNA: circadian variation in normal and Brattleboro rats. Science 232:390-393. CrossRef Medline

Van der Beek EM, Horvath TL, Wiegant VM, Van den Hurk R, Buijs RM (1997) Evidence for a direct neuronal pathway from the suprachiasmatic nucleus to the gonadotropin-releasing hormone system: combined tracing and light and electron microscopic immunocytochemical studies. J Comp Neurol 384:569-579. CrossRef Medline

Vida B, Deli L, Hrabovszky E, Kalamatianos T, Caraty A, Coen CW, Liposits Z, Kalló I (2010) Evidence for suprachiasmatic vasopressin neurones innervating kisspeptin neurones in the rostral periventricular area of the 
mouse brain: regulation by oestrogen. J Neuroendocrinol 22:1032-1039. CrossRef Medline

Watson RE Jr, Langub MC Jr, Engle MG, Maley BE (1995) Estrogenreceptive neurons in the anteroventral periventricular nucleus are synaptic targets of the suprachiasmatic nucleus and peri-suprachiasmatic region. Brain Res 689:254-264. CrossRef Medline

Wiegand SJ, Terasawa E, Bridson WE, Goy RW (1980) Effects of discrete lesions of preoptic and suprachiasmatic structures in the female rat. Alterations in the feedback regulation of gonadotropin secretion. Neuroendocrinology 31:147-157. CrossRef Medline

Williams WP 3rd, Jarjisian SG, Mikkelsen JD, Kriegsfeld LJ (2011) Circadian control of kisspeptin and a gated GnRH response mediate the preovulatory luteinizing hormone surge. Endocrinology 152:595-606. CrossRef Medline

Wintermantel TM, Campbell RE, Porteous R, Bock D, Gröne HJ, Todman MG, Korach KS, Greiner E, Pérez CA, Schütz G, Herbison AE (2006)
Definition of estrogen receptor pathway critical for estrogen positive feedback to gonadotropin-releasing hormone neurons and fertility. Neuron 52:271-280. CrossRef Medline

Xu Z, Kaga S, Tsubomizu J, Fujisaki J, Mochiduki A, Sakai T, Tsukamura H, Maeda K, Inoue K, Adachi AA (2011) Circadian transcriptional factor DBP regulates expression of Kiss 1 in the anteroventral periventricular nucleus. Mol Cell Endocrinol 339:90-97. CrossRef Medline

Zariwala HA, Borghuis BG, Hoogland TM, Madisen L, Tian L, De Zeeuw CI, Zeng H, Looger LL, Svoboda K, Chen TW (2012) A Cre-dependent GCaMP3 reporter mouse for neuronal imaging in vivo. J Neurosci 32: 3131-3141. CrossRef Medline

Zhang C, Tonsfeldt KJ, Qiu J, Bosch MA, Kobayashi K, Steiner RA, Kelly MJ, Rønnekleiv OK (2013) Molecular mechanisms that drive estradiol-dependent burst firing of Kiss1 neurons in the rostral periventricular preoptic area. Am J Physiol Endocrinol Metab 305: E1384-E1397. CrossRef Medline 